\title{
Correlation Between Atopic Dermatitis and Sleep Quality Among Adults in Saudi Arabia
}

\author{
Waad Alomayri $^{1}$, Nawal Alanazi ${ }^{1}$, Fatma Faraj $^{2}$ \\ 1. Department of Family Medicine, Family Medicine Residency Training Program, King Salman Armed Forces Hospital, \\ Tabuk, SAU 2. Department of Family Medicine, King Salman Armed Forces Hospital, Tabuk, SAU
}

Corresponding author:Waad Alomayri,waad.alomairi@hotmail.com

\section{Abstract \\ Background}

Atopic dermatitis is a chronic inflammatory skin disease characterized by pruritic, dry, and eczematous lesions. The effect of atopic dermatitis on the quality of patients' lives has been investigated. However, its impact on the quality of sleep is still controversial.

\section{Objective}

This study aims to identify the correlation between sleep quality and atopic dermatitis disease among adults living in Saudi Arabia.

\section{Design and setting}

This is a cross-sectional, quantitative survey study, carried out during July and August 2020, which included atopic dermatitis patients. The study used Arabic versions of a self-administered, Internet-based questionnaire of the Pittsburgh Sleep Quality Index (PSQI) and Dermatology Life Quality Index (DLQI). Face-to-face patient interviews were not applicable due to the COVID-19 pandemic.

\section{Results}

A total of 400 patients participated in this survey study. Eighty-six percent (86\%) were females while $39.6 \%$ were in the age group of 18 to 25 years old. A third of the responders could not sleep within half an hour, and a third of them woke up at night or early in the morning more than three times a week. Twenty-three point eight percent (23.8\%) of the responders rated their sleep quality as a very good quality of sleep while $17.8 \%$ rated it as very bad. Inability to get to sleep within half an hour ( $\mathrm{p}$-value $=0.002$ ), waking up at night ( $\mathrm{p}$ value $=0.005$ ), and not being able to sleep because of pain ( $p$-value $<0.001$ ) were all significantly correlated to the occurrence of many or a lot of skin symptoms of atopic dermatitis. There was a significantly higher total score among patients with atopic dermatitis ( $\mathrm{p}$ value $<0.001$ ), which shows a poorer quality of sleep.

Review began 12/01/2020 Review ended 12/06/2020 Published 12/13/2020

\section{○ Copyright 2020}

Alomayri et al. This is an open access article distributed under the terms of the Creative Commons Attribution License CC-BY 4.0., which permits unrestricted use, distribution, and reproduction in any medium, provided the original author and source are credited.

\section{Conclusion}

Symptoms of atopic dermatitis negatively influence the quality of sleep of adults in Saudi Arabia. The frequency of symptoms are significantly correlated to the poor quality of sleep. Therefore, we suggest that the evaluation of sleep quality is necessary for the management of atopic dermatitis patients.

Categories: Family/General Practice

Keywords: saudi arabia, atopic dermatitis, quality of sleep, quality of life

\section{Introduction}

Atopic dermatitis (AD) is a chronic inflammatory skin disease characterized by pruritic, dry, and eczematous lesions [1]. The prevalence of adult AD ranged from $2.1 \%$ to $4.9 \%$ across all countries. Prevalence is generally higher in females relative to males and is lower among older age groups, with a peak prevalence most frequently observed in the 25 to 34-year and 35 to 44-year age groups [2]. AD affects all races and geographic locations [3]. Their pathogenesis, however distinct, is multifactorial and encompasses a hyperactive immune system, environmental factors, and genetic predisposition [4]. Regarding the genetic predisposition, many patients affected by AD have a family history of atopies such as asthma, food allergies, $\mathrm{AD}$, or hay fever [3].

Pruritus is an essential symptom of $\mathrm{AD}$, so much so that $\mathrm{AD}$ is known as "the itch that rashes," which can affect sleep, quality of life (QoL), and different aspects of well-being in patients with $\mathrm{AD}$. Current published data demonstrate that $33 \%-87.1 \%$ of adults with $\mathrm{AD}$ suffer from sleep disturbance based on surveys of $\mathrm{AD}$ patients. Sleep insufficiency can lead to excessive daytime sleepiness, mood disturbance, and impaired cognition, which can then have an impact on work or school productivity, accidents, and adverse health 
outcomes, including metabolic, endocrine, and immune dysregulation, such as type 2 diabetes, high blood pressure and infection [5].

\section{Materials And Methods \\ Study design}

A cross-sectional study design was applied during July and August 2020.

\section{Study population}

Atopic dermatitis patients living in Saudi Arabia at the time of study conduction were eligible for inclusion in the study.

\section{Sample size}

We have used the following equation to calculate the sample size:

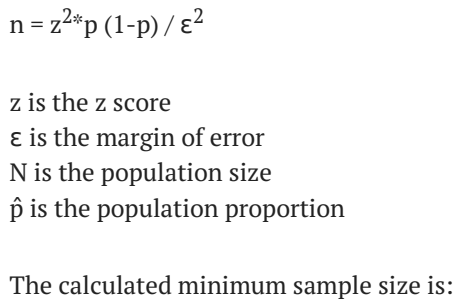

The calculated minimum sample size is:

$\mathrm{n}=(1.96)^{2 *} 0.5(1-0.5) /(0.05)^{2}=384.16$

A sample size of at least 385 people would be necessary.

\section{Data collection tool}

The study used the Arabic forms of a self-administered, Internet-based questionnaire of the Pittsburgh Sleep Quality Index (PSQI) and Dermatology Life Quality Index (DLQI). All patients provided electronic informed consent; permission to use the questionnaires was obtained through an e-mail communication with the authors.

Patients with $\mathrm{AD}$ were identified by the self-reported presence of $\mathrm{AD}$ by answering "yes" to the question "Have you been diagnosed with atopic dermatitis." This question, which required an affirmative answer, ensured the sample provided a truly representative population of patients with self-reported AD.

The PSQI questionnaire includes the demographic data of the respondents, subjective sleep quality, sleep latency, sleep duration, habitual sleep efficiency, sleep disturbances, use of sleeping medication, and daytime dysfunction. A global score of $\geqslant 5$ reflects a specific and sensitive measure of poor sleep quality [4].

The DLQI includes 10 questions, covering the following topics: symptoms, embarrassment, shopping and home care, clothes, social and leisure, sport, work or study, close relationships, sex, and treatment. Each question refers to the impact of the skin disease on the patient's life over the last week.

\section{Data entry and analysis}

All collected data were entered and analyzed using the Statistical Package for Social Science (SPSS) version 26. A p-value of less than or equal to 0.05 was utilized as a cut-off for statistical significance. A necessary statistical test was used as appropriate, e.g., the chi-squared test.

\section{Results}

This quantitative study included 400 patients who had been diagnosed with atopic dermatitis in Saudi Arabia. The self-administered questionnaire was carried out between July and August 2020. All descriptive and comparative analyses are shown below.

\section{Demographics of patients}

Among the 400 patients, $86 \%$ were females while age was subcategorized into five age groups. Thirty-nine point six percent (39.60\%) of the responders were in the age group of 18 to 25 years old, as shown in Figure 1. 


\section{Cureus}

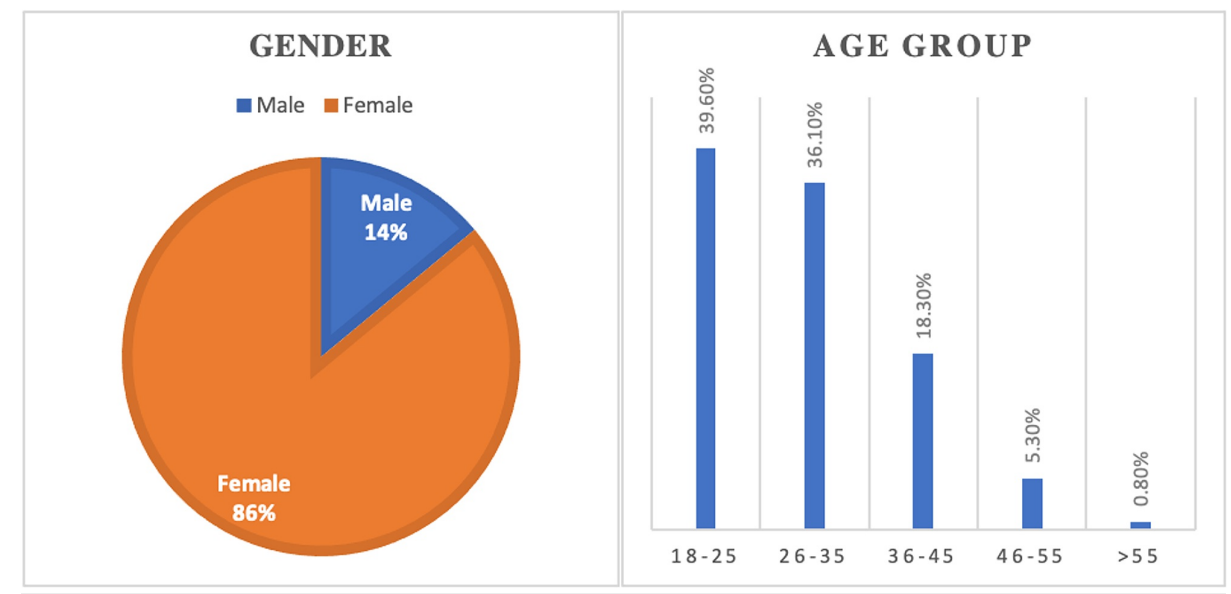

FIGURE 1: Demographics of patients.

\section{Sleep disturbances during the last month}

Participants were asked about their sleep habits and routines during the last month. Almost a third of the responders could not fall asleep within half an hour. Additionally, about a third of the responders woke up at night or early in the morning more than three times a week. Additionally, $16 \%$ of the responders could not sleep because of pain, $6 \%$ used over-the-counter medications (OTC) or prescribed medicine to sleep, and $6.5 \%$ had difficulty staying awake during different activities three or more times a week, as shown in Table 1.

\begin{tabular}{|c|c|c|c|}
\hline Item description & & Count & Percent \\
\hline \multirow{4}{*}{ Could not sleep within 30 minutes } & Not during the last month & 74 & 18.5 \\
\hline & Less than once a week & 63 & 15.8 \\
\hline & Once or twice a week & 110 & 27.6 \\
\hline & Three times or more/week & 153 & 38.1 \\
\hline \multirow{4}{*}{ Waking up in the middle of the night or early in the morning } & Not during the last month & 84 & 21.1 \\
\hline & Less than once a week & 82 & 20.6 \\
\hline & Once or twice a week & 112 & 28.1 \\
\hline & Three times or more/week & 122 & 30.3 \\
\hline \multirow{4}{*}{ Waking up to go to the bathroom } & Not during the last month & 94 & 23.6 \\
\hline & Less than once a week & 116 & 28.8 \\
\hline & Once or twice a week & 86 & 21.6 \\
\hline & Three times or more/week & 104 & 26.1 \\
\hline \multirow{4}{*}{ Cannot breathe comfortably } & Not during the last month & 228 & 56.9 \\
\hline & Less than once a week & 57 & 14.3 \\
\hline & Once or twice a week & 70 & 17.5 \\
\hline & Three times or more/week & 45 & 11.3 \\
\hline \multirow{4}{*}{ Coughing or loud snoring } & Not during the last month & 309 & 77.2 \\
\hline & Less than once a week & 57 & 14.3 \\
\hline & Once or twice a week & 16 & 4.0 \\
\hline & Three times or more/week & 18 & 4.5 \\
\hline & Not during the last month & 169 & 42.1 \\
\hline & Less than once a week & 112 & 28.1 \\
\hline
\end{tabular}




\section{Cureus}

\begin{tabular}{|c|c|c|c|}
\hline \multirow[t]{2}{*}{ Feeling very cold } & Once or twice a week & 72 & 18.0 \\
\hline & Three times or more/week & 47 & 11.8 \\
\hline \multirow{4}{*}{ Feeling very hot } & Not during the last month & 133 & 33.1 \\
\hline & Less than once a week & 93 & 23.3 \\
\hline & Once or twice a week & 105 & 26.3 \\
\hline & Three times or more/week & 69 & 17.3 \\
\hline \multirow{4}{*}{ Have bad dreams or nightmares } & Not during the last month & 145 & 36.1 \\
\hline & Less than once a week & 110 & 27.6 \\
\hline & Once or twice a week & 86 & 21.6 \\
\hline & Three times or more/week & 59 & 14.8 \\
\hline \multirow{4}{*}{ Have pain } & Not during the last month & 156 & 38.8 \\
\hline & Less than once a week & 102 & 25.6 \\
\hline & Once or twice a week & 78 & 19.5 \\
\hline & Three times or more/week & 64 & 16.0 \\
\hline \multirow{4}{*}{ Need prescribed or OTC medications to sleep } & Not during the last month & 320 & 79.9 \\
\hline & Less than once a week & 39 & 9.8 \\
\hline & Once or twice a week & 17 & 4.3 \\
\hline & Three times or more/week & 24 & 6.0 \\
\hline \multirow{4}{*}{ Difficulty staying awake while driving, eating meals, or engaging in social activities } & Not during the last month & 221 & 55.1 \\
\hline & Less than once a week & 88 & 22.1 \\
\hline & Once or twice a week & 65 & 16.3 \\
\hline & Three times or more/week & 26 & 6.5 \\
\hline \multirow{4}{*}{ Had a problem to keep up enough enthusiasm } & Three or more times a week & 39 & 9.8 \\
\hline & Once or twice a week & 100 & 25.1 \\
\hline & Less than once a week & 150 & 37.3 \\
\hline & Not during the past month & 111 & 27.8 \\
\hline
\end{tabular}

\section{TABLE 1: Sleep disturbances during the last month}

OTC: over the counter

Participants were also asked to rate their sleep during the last month; $23.8 \%$ of the responders had a very good quality of sleep while $17.8 \%$ had a very bad quality of sleep, as shown in Table 2 . 


\section{Cureus}

\begin{tabular}{|c|c|c|c|}
\hline Item description & & Count & Percent \\
\hline \multirow{4}{*}{ Overall sleep quality } & Very good & 95 & 23.8 \\
\hline & Fairly good & 178 & 44.4 \\
\hline & Fairly bad & 56 & 14.0 \\
\hline & Very bad & 71 & 17.8 \\
\hline
\end{tabular}

\section{TABLE 2: Evaluation of AD patients for their quality of sleep}

AD: atopic dermatitis

Furthermore, it has been shown that the most common time of going to sleep among the included cohort was 1:00 AM, where the average time taken to fall asleep each night was $23.4 \pm 10.8$ minutes. While the most common time of waking up was 8:00 AM, and the mean number of hours of actual sleep was 7.3 \pm 2.6 hours. Also, the mean number of times of interrupted sleep for causes outside of $\mathrm{AD}$ was $3.2 \pm 1.1$ times.

\section{Impact of atopic dermatitis on the quality of life}

Responders were also asked about how their atopic dermatitis symptoms are affecting their daily life activities. Almost a third of the patients described that their skin symptoms cause them some amount of pain or soreness, shame or embarrassment, or interference with social, sports, and other activities.

Additionally, only $10.8 \%$ of the patients found that their skin condition had affected their study or work, where $6.4 \%$ of these patients described the impaction as severe and significant.

Furthermore, less than a third of the patients described that their symptoms caused them little problems with their family and friends, sexual problems, or at home.

\section{Correlation between the presence of eczema and quality of sleep}

Patients' responses to questions related to the quality of sleep were compared over the presence of atopic dermatitis symptoms for the included patients using chi-square testing at the level of significance p-value $<0.05$.

It has been shown that an inability to get to sleep within half an hour (p-value=0.002), waking up at night (pvalue $=0.005$ ), and not being able to sleep because of pain ( $p$-value $<0.001$ ) were all significantly correlated to the occurrence of many or a lot of skin symptoms of atopic dermatitis, as shown in Table 3 .

\begin{tabular}{|c|c|c|c|c|c|c|}
\hline \multirow{2}{*}{ PSQI items } & & \multicolumn{4}{|c|}{ Itchy, painful, sore, or tingling } & \multirow{2}{*}{ p-value } \\
\hline & & $\begin{array}{l}\text { Very } \\
\text { much }\end{array}$ & A lot & A little & $\begin{array}{l}\text { Not at } \\
\text { all }\end{array}$ & \\
\hline \multirow{5}{*}{ Could not sleep within 30 minutes } & $\begin{array}{l}\text { Less than once a } \\
\text { week }\end{array}$ & $16.9 \%$ & $18.5 \%$ & $11.4 \%$ & $10.5 \%$ & \multirow{5}{*}{$0.002^{*}$} \\
\hline & $\begin{array}{l}\text { Once or twice a } \\
\text { week }\end{array}$ & $36.4 \%$ & $28.7 \%$ & $17.1 \%$ & $21.1 \%$ & \\
\hline & $\begin{array}{l}3 \text { or more times a } \\
\text { week }\end{array}$ & $53.3 \%$ & $33.8 \%$ & $33.2 \%$ & $26.3 \%$ & \\
\hline & $\begin{array}{l}\text { Not during the last } \\
\text { month }\end{array}$ & $14.4 \%$ & $19.1 \%$ & $18.1 \%$ & $42.1 \%$ & \\
\hline & $\begin{array}{l}\text { Less than once a } \\
\text { week }\end{array}$ & $23.7 \%$ & $22.3 \%$ & $12.4 \%$ & $31.6 \%$ & \\
\hline \multirow{2}{*}{ Waking up in the middle of the night or early } & $\begin{array}{l}\text { Once or twice a } \\
\text { week }\end{array}$ & $33.1 \%$ & $26.8 \%$ & $27.6 \%$ & $10.5 \%$ & \multirow{2}{*}{$0.005^{\star}$} \\
\hline & $\begin{array}{l}3 \text { or more times a } \\
\text { week }\end{array}$ & $44.8 \%$ & $24.2 \%$ & $25.4 \%$ & $31.6 \%$ & \\
\hline
\end{tabular}




\section{Cureus}

Waking up to go to the bathroom

Cannot breathe comfortably

Coughing or loud snoring

Feeling very cold

Feeling very hot

Have bad dreams or nightmares

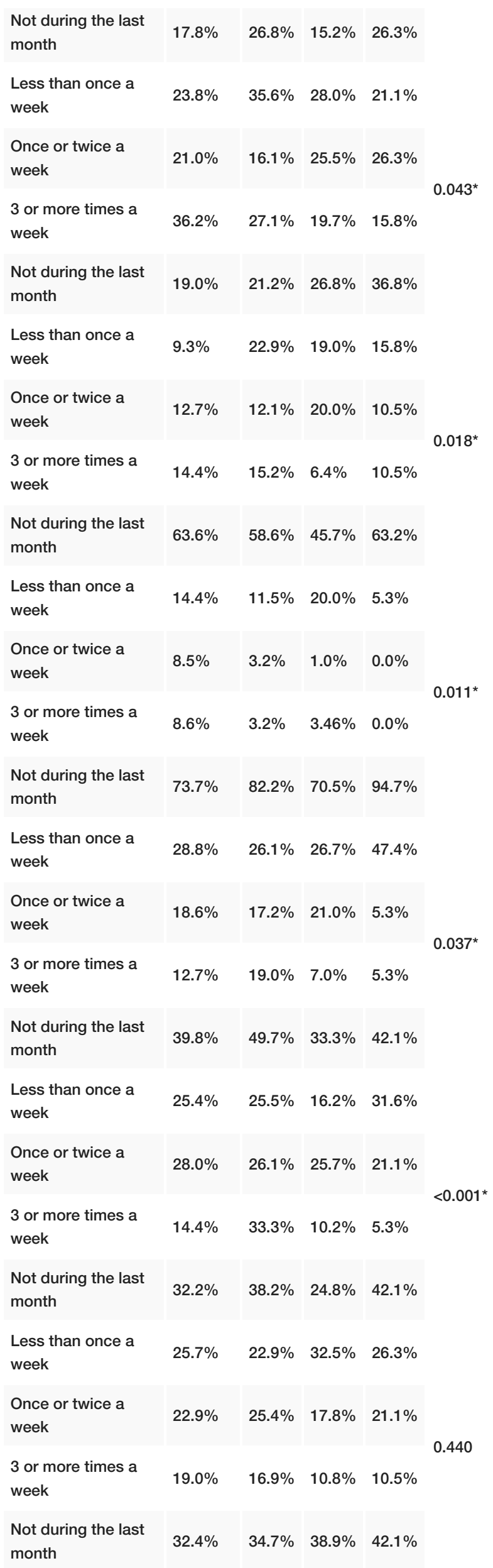




\section{Cureus}

\begin{tabular}{|c|c|c|c|c|c|c|}
\hline \multirow{4}{*}{ Have pain } & $\begin{array}{l}\text { Less than once a } \\
\text { week }\end{array}$ & $31.4 \%$ & $23.6 \%$ & $23.8 \%$ & $15.8 \%$ & \multirow{4}{*}{$<0.001^{*}$} \\
\hline & $\begin{array}{l}\text { Once or twice a } \\
\text { week }\end{array}$ & $20.3 \%$ & $16.6 \%$ & $23.8 \%$ & $15.8 \%$ & \\
\hline & $\begin{array}{l}3 \text { or more times a } \\
\text { week }\end{array}$ & $16.1 \%$ & $28.6 \%$ & $8.9 \%$ & $5.3 \%$ & \\
\hline & $\begin{array}{l}\text { Not during the last } \\
\text { month }\end{array}$ & $32.2 \%$ & $51.0 \%$ & $23.8 \%$ & $63.2 \%$ & \\
\hline \multirow{4}{*}{ Need over-the-counter medicines to sleep } & $\begin{array}{l}\text { Less than once a } \\
\text { week }\end{array}$ & $11.4 \%$ & $10.2 \%$ & $7.6 \%$ & $15.8 \%$ & \multirow{4}{*}{0.530} \\
\hline & $\begin{array}{l}\text { Once or twice a } \\
\text { week }\end{array}$ & $2.9 \%$ & $5.1 \%$ & $5.1 \%$ & $0.0 \%$ & \\
\hline & $\begin{array}{l}3 \text { or more times a } \\
\text { week }\end{array}$ & $8.6 \%$ & $7.6 \%$ & $3.8 \%$ & $0.0 \%$ & \\
\hline & $\begin{array}{l}\text { Not during the last } \\
\text { month }\end{array}$ & $77.1 \%$ & $77.1 \%$ & $83.4 \%$ & $84.2 \%$ & \\
\hline \multirow{4}{*}{$\begin{array}{l}\text { Difficulty staying awake while driving, eating meals, or engaging } \\
\text { in social activities }\end{array}$} & $\begin{array}{l}\text { Less than once a } \\
\text { week }\end{array}$ & $27.6 \%$ & $19.5 \%$ & $21.0 \%$ & $15.8 \%$ & \multirow{4}{*}{0.072} \\
\hline & $\begin{array}{l}\text { Once or twice a } \\
\text { week }\end{array}$ & $16.2 \%$ & $22.0 \%$ & $12.7 \%$ & $10.5 \%$ & \\
\hline & $\begin{array}{l}3 \text { or more times a } \\
\text { week }\end{array}$ & $10.5 \%$ & $6.8 \%$ & $4.5 \%$ & $0.0 \%$ & \\
\hline & $\begin{array}{l}\text { Not during the last } \\
\text { month }\end{array}$ & $45.7 \%$ & $51.7 \%$ & $61.8 \%$ & $73.7 \%$ & \\
\hline \multirow{4}{*}{ Had a problem to keep up enough enthusiasm } & $\begin{array}{l}\text { Less than once a } \\
\text { week }\end{array}$ & $36.2 \%$ & $42.4 \%$ & $34.4 \%$ & $36.8 \%$ & \multirow{4}{*}{0.093} \\
\hline & $\begin{array}{l}\text { Once or twice a } \\
\text { week }\end{array}$ & $28.6 \%$ & $29.7 \%$ & $20.4 \%$ & $15.8 \%$ & \\
\hline & $\begin{array}{l}3 \text { or more times a } \\
\text { week }\end{array}$ & $11.4 \%$ & $3.4 \%$ & $13.4 \%$ & $10.5 \%$ & \\
\hline & $\begin{array}{l}\text { Not during the last } \\
\text { month }\end{array}$ & $23.8 \%$ & $24.6 \%$ & $31.8 \%$ & $36.8 \%$ & \\
\hline \multirow{4}{*}{ Overall sleep quality } & Very good & $16.2 \%$ & $23.7 \%$ & $28.7 \%$ & $26.3 \%$ & \multirow{4}{*}{0.507} \\
\hline & Good & $43.8 \%$ & $45.8 \%$ & $43.9 \%$ & $42.1 \%$ & \\
\hline & $\mathrm{Bad}$ & $16.2 \%$ & $12.7 \%$ & $13.4 \%$ & $15.8 \%$ & \\
\hline & Very bad & $23.8 \%$ & $17.8 \%$ & $14.0 \%$ & $15.8 \%$ & \\
\hline
\end{tabular}

TABLE 3: Correlation between atopic dermatitis (AD) symptoms frequency in the Dermatology Life Quality Index (DLQI) and each question in Pittsburgh Sleep Quality Index (PSQI)

Moreover, the PSQI global score was also calculated and compared over patients with itchy, sore, painful skin over the last week and patients who didn't have symptoms at all over the last week. It has been shown that there was a significantly higher total score among patients with active symptoms of atopic dermatitis last week ( $p$-value $<0.001$ ), which shows a poorer quality of sleep as compared to other subjects, as shown in Table 4. 


\section{Cureus}

\begin{tabular}{|c|c|c|c|c|c|}
\hline \multirow[t]{3}{*}{ PSQI component } & \multicolumn{4}{|c|}{ AD symptoms over the past week } & \multirow[t]{3}{*}{ p-value } \\
\hline & \multicolumn{2}{|c|}{ active symptoms } & \multicolumn{2}{|c|}{ inactive symptoms } & \\
\hline & Mean & SD & Mean & SD & \\
\hline Subjective sleep quality & 1.3 & 0.2 & 0.8 & 0.1 & 0.023 \\
\hline Sleep latency & 1.8 & 0.6 & 1.1 & 0.3 & $<0.001$ \\
\hline Sleep duration & 1.3 & 0.1 & 0.6 & 0.1 & $<0.001$ \\
\hline Habitual sleep efficiency & 1.9 & 0.4 & 1.2 & 0.5 & 0.036 \\
\hline Sleep disturbance & 1.6 & 0.1 & 0.7 & 0.2 & $<0.001$ \\
\hline Use of sleep medications & 0.7 & 0.3 & 0.3 & 0.1 & 0.014 \\
\hline Daytime dysfunction & 0.6 & 0.3 & 0.4 & 0.1 & $<0.001$ \\
\hline Total score & 7.6 & 2.3 & 2.9 & 1.3 & $<0.001$ \\
\hline
\end{tabular}

TABLE 4: Pittsburgh Sleep Quality Index (PSQI) domains among atopic dermatitis (AD) patients with active and inactive symptoms

\section{Discussion}

Atopic dermatitis is one of the most common skin conditions accompanied by significant soreness and dryness of the skin [6]. Patients with atopic dermatitis usually suffer from social embarrassment and a significant impact on their quality of life [7]. Additionally, the severity and frequency of atopic dermatitis symptoms have also been correlated to sleep disturbances; however, this correlation is still unclear in the Saudi population [8].

The present study examined the correlation of atopic dermatitis symptoms and sleep disturbances among adults living in Saudi Arabia. The study demonstrated that sleep quality was affected in at least one-third of the responders due to atopic dermatitis skin symptoms. Furthermore, $23.8 \%$ of the responders described their sleep quality as a very good quality of sleep; while $17.8 \%$ described it as very bad, $14 \%$ had a fairly bad quality of sleep. Moreover, the total score for sleep quality indicated significantly worse sleep quality in patients with active atopic dermatitis symptoms (p-value<0.001).

The impact of atopic dermatitis on sleep quality has been evaluated in different settings. Sherry et al. identified fatigue and burden accompanied by sleep among adults with atopic dermatitis in the United States [9]. Through surveying 5563 adults, respondents were asked about a history of atopic dermatitis, fatiguerelated instrumental activity of daily living (IADL) impairment, and sleep disturbance. Additionally, the authors illustrated that adults with atopic dermatitis showed significantly impaired sleep and fatigue, affecting their daily life activities, and highlighted that sleep disturbances might be underdiagnosed. Similarly, our study demonstrated that $17.3 \%$ of the responders found their symptoms interfere with daily life activities. Also, $10.8 \%$ of the included patients found their symptoms affect their occupational life.

Another study was by Kong et al., which evaluated the relationships between clinical disease severity, quality of life, and sleep quality in both children and adults with atopic dermatitis [10]. Both the Children's Sleep Habits Questionnaire (CSHQ) and the Children's Dermatology Life Quality Index (CDLQI) were used for children, while PSQI and DLQI were used in adult atopic dermatitis patients and demonstrated that increasing severity of $\mathrm{AD}$ affects sleep quality in children and significant correlation between the severity of atopic dermatitis and poor quality of life in adults, despite the insignificant correlation with sleep quality, which supports the findings of the present study.

However, the present study examined only adults, where the responders couldn't fall asleep within half an hour ( $\mathrm{p}$-value=0.002), waking up at night ( $\mathrm{p}$-value=0.005), not breathing comfortably at night ( $\mathrm{p}$ value $=0.018$ ), coughing and snoring during sleep ( $p$-value $=0.011$ ), being unable to sleep well because feeling very cold ( $\mathrm{p}$-value $=0.037$ ) or very hot ( $\mathrm{p}$-value $<0.001$ ), not being able to sleep because of pain ( $\mathrm{p}$ value $<0.001$ ), were all significantly correlated to the occurrence of many or a lot of skin symptoms of atopic dermatitis.

These outcomes were also congruent with Silverberg et al., which reported an association between adult atopic dermatitis and altered sleep duration, fatigue, and sleep disturbances, including daytime sleepiness and insomnia [11]. Although adults with atopic dermatitis were more likely to report fair/poor health, the 
presence of sleep disturbances in combination with eczema significantly increased the rates of fair/poor health.

Finally, the present study had some limitations; Face-to-face interviews were planned to take place with patients; however, due to the COVID-19 pandemic, the questionnaire was carried out online due to clinic closures. Additionally, the responses to this survey depended mainly on patients' subjective opinions, which might affect the results' reliability.

\section{Conclusions}

Patients with atopic dermatitis significantly suffer from sleep disturbances. The extent of the affection of sleep quality is correlated to the frequency of skin symptoms. These findings can help clinicians understand the clinical manifestations and presenting symptoms of patients with atopic dermatitis. Further studies are required to explore methods to improve the quality of sleep in this particular patient population and adequate guidelines for treating or evaluating $\mathrm{AD}$ patients' sleep disorders.

\section{Additional Information}

\section{Disclosures}

Human subjects: Consent was obtained by all participants in this study. Animal subjects: All authors have confirmed that this study did not involve animal subjects or tissue. Conflicts of interest: In compliance with the ICMJE uniform disclosure form, all authors declare the following: Payment/services info: All authors have declared that no financial support was received from any organization for the submitted work. Financial relationships: All authors have declared that they have no financial relationships at present or within the previous three years with any organizations that might have an interest in the submitted work. Other relationships: All authors have declared that there are no other relationships or activities that could appear to have influenced the submitted work.

\section{References}

1. Garg N, Silverberg JI: Association between childhood allergic disease, psychological comorbidity, and injury requiring medical attention. Ann Allergy Asthma Immunol. 2014, 112:525-532. 10.1016/j.anai.2014.03.006

2. Barbarot S, Auziere S, Gadkari A, et al.: Epidemiology of atopic dermatitis in adults: results from an international survey. Allergy. 2018, 73:1284-1293.

3. Lifschitz C: The impact of atopic dermatitis on quality of life . Ann Nutr Metab. 2015, 66:34-40. 10.1159/000370226

4. Kaaz K, Szepietowski J, Matusiak L: Influence of itch and pain on sleep quality in atopic dermatitis and psoriasis. Acta Derm Venereol. 2019, 99:175-180. 10.2340/00015555-3065

5. Jeon C, Yan D, Nakamura M, Sekhon S, Bhutani T, Berger T, Liao W: Frequency and management of sleep disturbance in adults with atopic dermatitis: a systematic review. Dermatol Ther. 2017, 7:349-364. 10.1007/s13555-017-0192-3

6. Vakharia PP, Chopra R, Sacotte R, et al.: Burden of skin pain in atopic dermatitis. Ann Allergy Asthma Immunol. 2017, 119:548-552. 10.1016/j.anai.2017.09.076

7. Silverberg JI, Gelfand JM, Margolis DJ, et al.: Patient burden and quality of life in atopic dermatitis in US adults: a population-based cross-sectional study. Ann Allergy Asthma Immunol. 2018, 121:340-347. 10.1016/j.anai.2018.07.006

8. Vakharia PP, Chopra R, Sacotte R, et al.: Validation of patient-reported global severity of atopic dermatitis in adults. Allergy. 2018, 73:451-458.

9. Sherry HY, Attarian H, Zee P, Silverberg JI: Burden of sleep and fatigue in US adults with atopic dermatitis . Dermatitis. 2016, 1:50-58. 10.1097/DER.0000000000000161

10. Kong TS, Han TY, Lee JH, Son SJ: Correlation between severity of atopic dermatitis and sleep quality in children and adults. Ann Dermatol. 2016, 28:321-326. 10.5021/ad.2016.28.3.321

11. Silverberg JI, Garg NK, Paller AS, Fishbein AB, Zee PC: Sleep disturbances in adults with eczema are associated with impaired overall health: a US population-based study. J Invest Dermatol. 2015, 135:56-66. 10.1038/jid.2014.325 